\title{
The Cell Therapy Catapult: Growing a U.K. Cell Therapy Industry Generating Health and Wealth
}

\author{
Keith Thompson and Emma Palmer Foster*
}

In a recent report on the regenerative medicine sector, the U.K. House of Lords made several recommendations to enable the United Kingdom to become a global leader in this important industry. Its recommendations in this regard were many and various, covering the regulatory system, clinical trials, manufacturing, funding, approval, and reimbursement. In its mission to tackle what it sees as three main types of barriers to the development of the cell therapy industry in the United Kingdom, the Cell Therapy Catapult is tackling many of these issues. Established as a center of excellence in the United Kingdom in 2012, the Cell Therapy Catapult is a research organization expected to grow to a team of around 100 experts. Its core financing of $£ 70$ million over the next 5 years is provided by the Technology Strategy Board, the United Kingdom's innovation agency, and with additional contract research income and access to collaborative funds, the Catapult expects to build up to annual revenues of around $£ 30$ million. Along with its sister Catapult programs in other areas of the economy, the Cell Therapy Catapult was established after identification of the massive early-stage expertise the country has, as well as an acute market failure-the lack of expertise to translate early-stage cell therapy research into commercial success. In this article, in addition to showing our progress so far, we will discuss the hurdles the industry faces-grouped into business, manufacturing/supply chain issues, and clinical/regulatory issuesand what we are doing to help the United Kingdom leap over them.

The conclusions of the U.K. House of Lords Science and Technology Committee's recent review of the regenerative medicine sector were eagerly awaited. The committee's report, published in July 2013, noted huge promise in this area [101].

[l]t has enormous potential to treat and cure diseases. It could also improve the quality of people's lives

Cell Therapy Catapult, London, United Kingdom. *(Correspondence: emma.palmerfoster@ct. catapult.org.uk) and generate significant economic benefits for the UK.

It praised the United Kingdom's strengths in this area-and also sounded a warning.

The UK has many strengths in regenerative medicine, including: an excellent basic science base, potential access to hundreds of patients in a unified healthcare system, and experienced blood and transfusion services, clinicians and scientists.
The UK has the chance to be a leader in this field, and this opportunity must not be missed.

Noting the promising work of the Cell Therapy Catapult, it made several recommendations to enable the United Kingdom to become a global leader in this important industry. Its recommendations in this regard were many and various, covering the regulatory system, clinical trials, manufacturing, funding, approval, and reimbursement. 
FIG. 1. Addressing barriers in the United Kingdom.

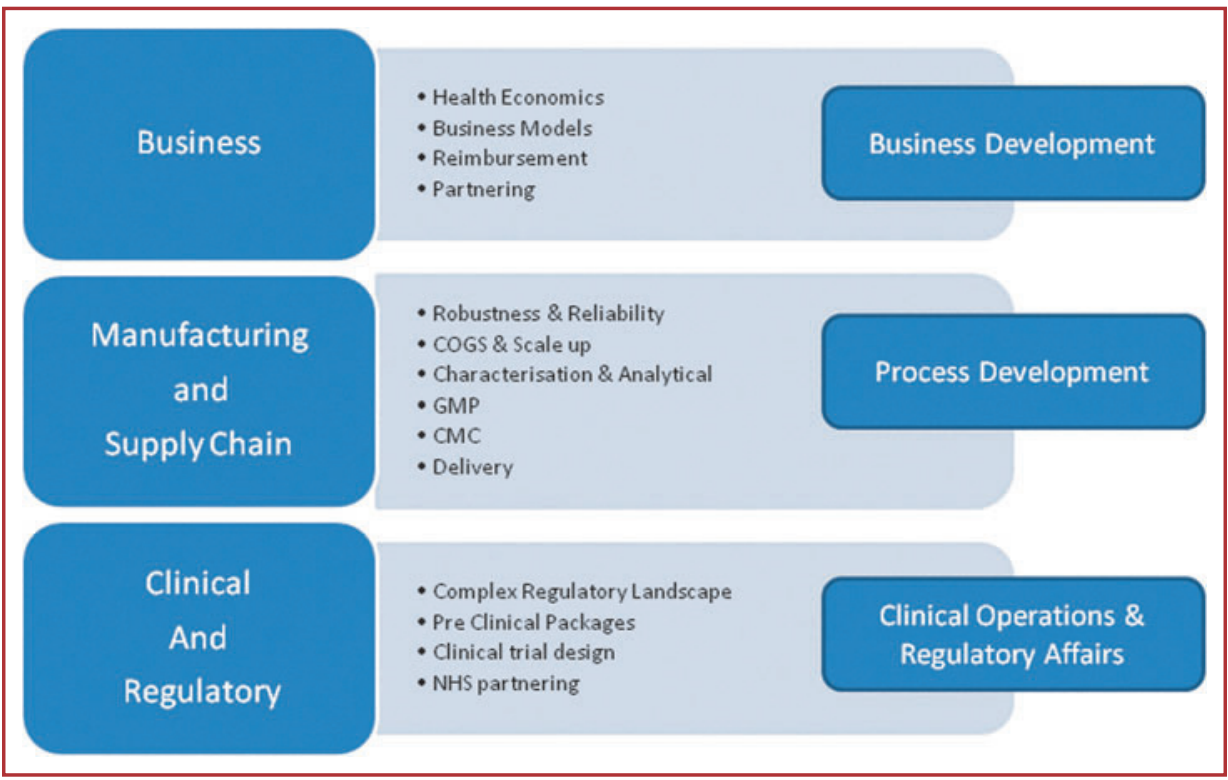

FIG. 2. The Cell Therapy Catapult vision.

The Cell Therapy Catapult vision is for the UK to be
a global leader in the development, delivery and
commercialisation of cell therapy - a place where
businesses can start, grow and confidently develop cell
therapies, delivering them to patients rapidly, efficiently and
effectively.

FIG. 3. The Cell Therapy Catapult mission.

The Cell Therapy Catapult will grow the industry in the UK to substantial and sustainable levels by :

Taking products into clinical trial, de-risking them for further investment Providing clinical expertise and access to NHS clinical partners

Providing technical expertise and infrastructure to ensure products can be made to GMP and delivered cost effectively

Providing regulatory expertise to ensure that products can get to the clinic safely in the shortest time

Providing opportunities for collaboration, nationally and globally

Providing access to business expertise, grants and investment finance so that commercially viable products are progressed and investable propositions generated

In its mission to tackle what it sees as three main types of barriers to the development of the cell therapy industry in the United Kingdom, the Cell Therapy Catapult is tackling many of these issues (Fig. 1). In this article, as well as showing our progress so far, we will discuss these hurdles - grouped into business, manufacturing/supply chain issues, and clinical/regulatory issuesand what we are doing to enable the United Kingdom to leap over them.

Established as a center of excellence in the United Kingdom in 2012, the Cell Therapy
Catapult is a research organization expected to grow to a team of around 100 experts. Its core financing of $£ 70$ million over the next 5 years is from the Technology Strategy Board, the United Kingdom's innovation agency, and with additional contract research income and access to collaborative funds the Catapult expects to build to annual revenues of around $£ 30$ million. Along with its sister Catapult programs in other areas of the economy [102], the Cell Therapy Catapult was established after the identification of the massive earlystage expertise the country has, as well as an acute market failure - the lack of expertise to translate early-stage cell therapy research into commercial success.

The Catapult program is business led, based on the best aspects of technology innovation centers worldwide, and arose from a report from technology entrepreneur Herman Hauser. In his 2010 review, he discussed how to exploit the U.K. science base better, create new manufacturing industries for the United Kingdom, and enable industries to "grow and stick" in this country. Certain criteria were used in choosing the sectors that would benefit from Catapult activity as follows:

- Ability to generate more than $£ 10$ billion in long-term industrial revenue for the United Kingdom

- Presence of a strong U.K. science base in that area

- Ability and capacity of the United Kingdom to capture and retain the various kinds of capital generated (from financial to skills)

- The need for translational activity in order to bridge the funding gap

The Cell Therapy Catapult's vision and mission fall quite naturally from this (Figs 2,3). Our strategic goals are centered around building a pipeline, building value, showing the attractiveness of the United Kingdom for cell therapy work, and building an industry whose future value could be $£ 10$ billion-so generating health and wealth in the United Kingdom. We can measure the U.K. cell therapy industry in terms of what products and projects are in clinical trial and which products are 
on the market. In addition, capturing "grow and stick" value in the United Kingdom is about helping to generate investible projects and companies that find the supportive environment they need in the United Kingdom, so that they see no reason to move elsewhere. This is expected to lead to increased inward investment as well.

As it does its work of helping to cross the translational gap (Fig. 4), the Cell Therapy Catapult will be generating a range of outputs, one of the ways in which it will be assessing its progress. The kinds of outputs it is expecting to generate are as follows:

- Investible therapies with a rounded and complete phase II data package. In many cases, investors have been reluctant to invest in this area based on previous failures and the existence of both perceived and real risk. We believe that the expertise of the Cell Therapy Catapult team, working with the United Kingdom and global communities, will increase the number of projects, making it through phase II as compelling investment opportunities. Indeed, there has already been early evidence of how interaction with the Cell Therapy Catapult could lead to increased investor confidence, with the recent news that one of our partners, ReNeuron, has received a $£ 33$ million financing package, comprising $£ 25$ million in equity and $£ 8$ million in grants.

- This increased confidence and later stage of development will also be shown in increased in-licensing activity by the industry.

- Case studies on how we have helped companies and the industry over barriers

- A streamlined regulatory environmentfor instance, U.K. regulators have already changed the ethical approval process for clinical trials to under 60 days.

- Enhanced capability of the U.K. industry through contract research that helps in the development of new skills and capabilities

- Skilled, trained, and experienced professionals

FIG. 4. Mind the (translational funding) gap.

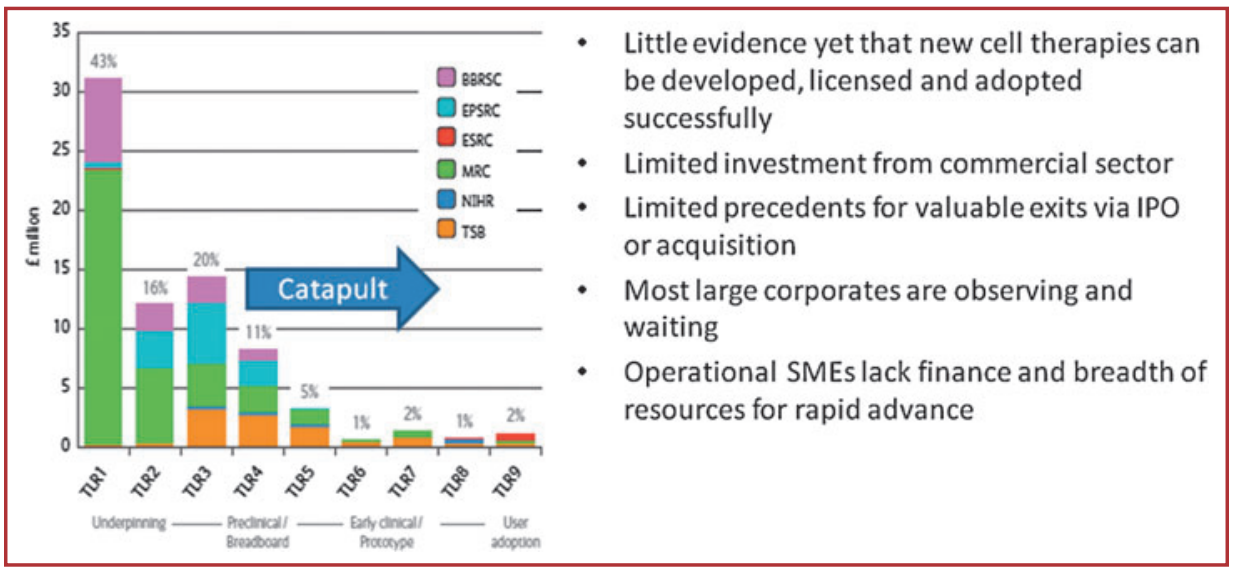

FIG. 5. The Cell Therapy Catapult pipeline.

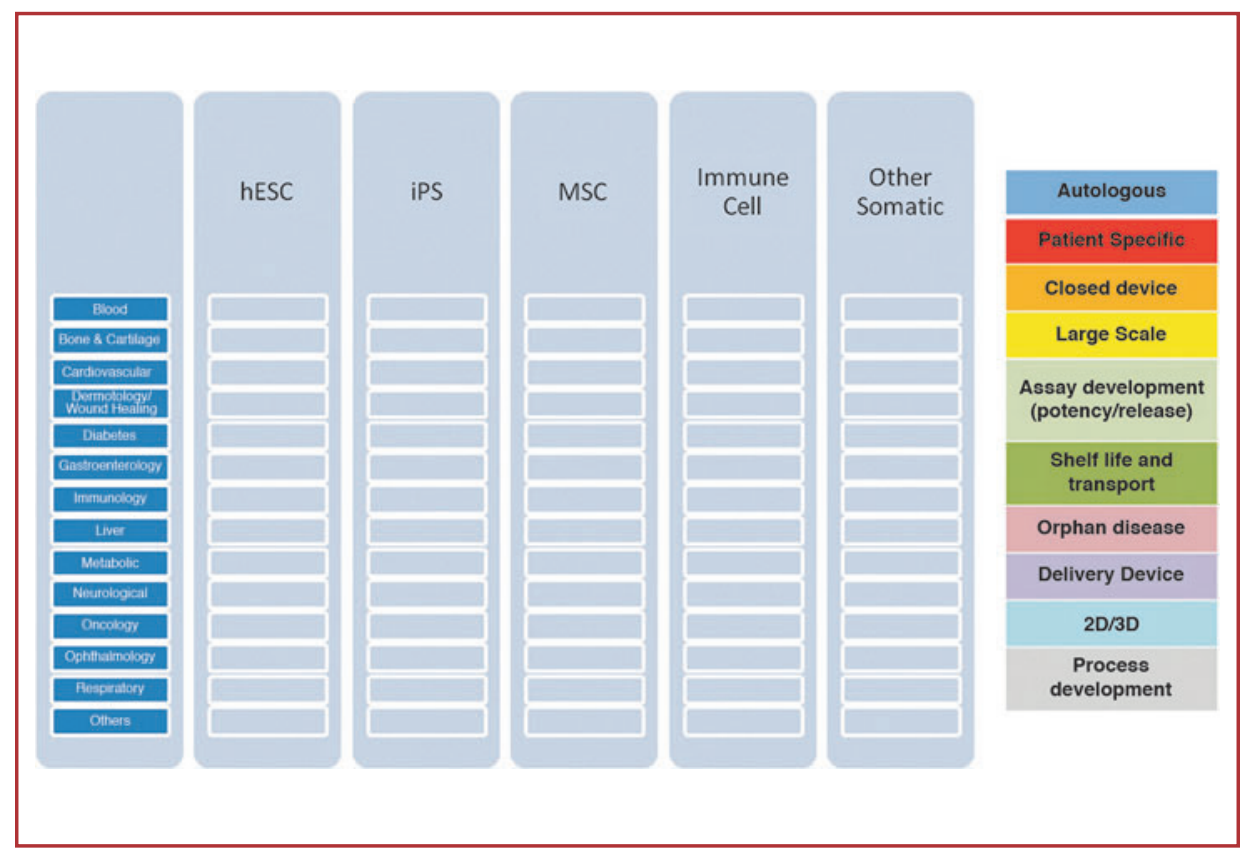

In response to our mission to tackle the three barriers to translation activity in the U.K. cell therapy industry, the Cell Therapy Catapult is organized into teams along these lines, as follows:

- Financial and business development, covering the generation of projects to fill the Cell Therapy Catapult pipeline, partnering, health economics modeling, reimbursement, and innovative business modeling (in addition to organizational functions). The Cell Therapy Catapult is able to carry out three kinds of projects: projects (from therapies to platforms) in which we can invest directly and which we describe as "core"; projects as part of collaborative teams; and projects through contract research. Even contract research has a strategic function for us in that we are keen to undertake work where an important new skill is learned or inward investment is a possible long-term outcome. In terms of our pipeline, we envisage it very much along the lines shown in Figure 5. From this it is clear that we are keen to tackle a variety of diseases and indications using a range of cell types. In addition, the challenges listed on the right-hand side of Figure 5 show the 
range of issues we wish to tackle on behalf of the industry.

- Process development, covering manufacturing and supply chain expertise, cost of goods sold and scale-up, characterization and analytical work, delivery research, and good manufacturing practice activities. By the first quarter of 2014, the Cell Therapy Catapult will be occupying $1,200 \mathrm{~m}^{2}$ of state-of-theart new facilities at Guy's Hospital London. This will comprise laboratory and office space designed for maximum interaction among all members of the team and visitors. An important part of the offering is the GMP-proving laboratories, providing an important intermediate step between early-stage research and large-scale production and a key part of our translational offering. In addition to the services available at the Cell Therapy Catapult, our location with the U.K. National Institute for Health Research Biomedical Research Centre at Guy's and St. Thomas' NHS Foundation Trust and King's College London provides easy access to research technologies, such as genomics, as well as a clinical research facility. More generally, we benefit from being part of the rich academic and clinical network in the United Kingdom.

- Clinical operations and regulatory affairs, with expertise in the complex regulatory landscape; preclinical package design; clinical trial design; and access to the patient, clinician, and clinical trials networks within the NHS.

Some of the earliest work we did at the Cell Therapy Catapult was to review the U.K. cell therapy preclinical project pipeline and clinical trial activity. The preclinical database of projects, expected to enter the clinic in 2 years or less, is a valuable guide to developing trends and will guide our future activities. In turn, the clinical trial database helps identify potential projects for collaboration and future development, as well as monitoring our progress in helping to grow the U.K. cell therapy industry. With 37 preclinical research projects ongoing in the United Kingdom and 34 clinical trials, these 71 activities provide a snapshot of the sector as it stands at the moment, with regular updates of the databases expected.

It is clear that for all this excellent research to be translated and exploited in the United Kingdom, with associated economic benefit to the country, there needs to be sufficient manufacturing capacity. This is required not only to serve those organizations already present in the United Kingdom, but also to provide a capacity and skills base to attract inward investment. We have assessed the United Kingdom's preparedness in this area, using our research databases,

\section{Table 1. The Cell Therapy Catapult's Recent Partnerships}

\begin{tabular}{|c|c|c|c|}
\hline Date & Partner type & Partner & Details \\
\hline March 2013 & U.K. small company & ReNeuron & $\begin{array}{l}\text { Collaboration } \\
\text { around assay } \\
\text { development and } \\
\text { manufacturing } \\
\text { scale-up }\end{array}$ \\
\hline April 2013 & U.K. charity & $\begin{array}{l}\text { U.K. Stem Cell } \\
\text { Foundation }\end{array}$ & $\begin{array}{l}\text { Collaboration on } \\
\text { translational } \\
\text { projects }\end{array}$ \\
\hline April 2013 & U.K. university & $\begin{array}{l}\text { Loughborough } \\
\text { University }\end{array}$ & $\begin{array}{l}\text { Working on } \\
\text { manufacturing } \\
\text { and delivery } \\
\text { techniques, } \\
\text { skills \& training }\end{array}$ \\
\hline May 2013 & $\begin{array}{l}\text { U.K./global large } \\
\text { company }\end{array}$ & GlaxoSmithKline & $\begin{array}{l}\text { Potential collabora- } \\
\text { tions around } \\
\text { research projects, } \\
\text { technical and } \\
\text { regulatory strategy }\end{array}$ \\
\hline May 2013 & $\begin{array}{l}\text { Canadian not-for- } \\
\text { profit organization }\end{array}$ & $\begin{array}{l}\text { Canadian Centre for } \\
\text { Commercialisation } \\
\text { of Regenerative } \\
\text { Medicine }\end{array}$ & $\begin{array}{l}\text { Collaborating on } \\
\text { R\&D projects, } \\
\text { clinical trials, } \\
\text { standardization and } \\
\text { regulatory efforts, } \\
\text { plus training }\end{array}$ \\
\hline July 2013 & U.K. consortium & $\begin{array}{l}\text { Videregen Ltd., } \\
\text { NHS Blood and } \\
\text { Transplant, the } \\
\text { Royal Free London } \\
\text { NHS Foundation } \\
\text { Trust, and } \\
\text { University College } \\
\text { London, UCLB }\end{array}$ & $\begin{array}{l}\text { Further develop- } \\
\text { ment and early } \\
\text { clinical trials of } \\
\text { trachea replace- } \\
\text { ment prototype for } \\
\text { treatment of severe } \\
\text { structural airway } \\
\text { disease; the Cell } \\
\text { Therapy Catapult as } \\
\text { clinical trial sponsor } \\
\text { (plus regulatory } \\
\text { pathway expertise) }\end{array}$ \\
\hline
\end{tabular}

The U.K. Cell Therapy Catapult has clearly had a busy and productive first year in operation-with many challenges ahead. We are keen to work with the cell therapy community across the board, so do please get in touch and we look forward to hearing from you. 
combined with assumptions around attrition rates, new projects, and inward investment. The full conclusions of our analysis will be available in the autumn, along with recommendations on how to deal with the capacity requirements.

Finally, discussing some of the collaborations and partnerships that the Cell Therapy Catapult has signed recently gives a good indication of the range and scope of our activities as we work with the community to build a flourishing cell therapy industry. As Table 1 shows, we welcome the chance to interact and work with companies large and small, academic institutions, and charities both in the United Kingdom and internationally. Additionally, we are keen to bring our expertise and assets to project consortia.

\section{Author disclosure statement}

No competing financial interests exist.

\section{Websites}

101. http://publications.parliament.uk/pa/ ld201314/ldselect/ldsctech/23/23.pdf 102. https://catapult.org.uk 